\title{
Uptake, Partitioning, and Storage of Fertilizer Nitrogen in Red Raspberry as Affected by Rate and Timing of Application
}

\author{
Hannah G. Rempel, ${ }^{1}$ Bernadine C. Strik, ${ }^{2}$ and Timothy L. Righetti ${ }^{3}$ \\ Department of Horticulture, Oregon State University, Corvallis, OR 97331-7304
}

\begin{abstract}
AdDitional INDEX WORDS. ${ }^{15} \mathrm{~N}$, fertilizer recovery, Rubus idaeus, growth, summer-bearing raspberry, yield
Aвstract. The effects of ${ }^{15} \mathrm{~N}$-labeled fertilizer applied to mature summer-bearing red raspberry (Rubus idaeus $\mathrm{L}$. 'Meeker') plants were measured over 2 years. Four nitrogen $(\mathrm{N})$ treatments were applied: singularly at 0,40 , or 80 $\mathrm{kg} \cdot \mathrm{ha}^{-1}$ of $\mathrm{N}$ in early spring (budbreak), or split with $40 \mathrm{~kg} \cdot \mathrm{ha}^{-1}$ of $\mathrm{N}$ (unlabeled) applied at budbreak and $40 \mathrm{~kg} \cdot \mathrm{ha} \mathrm{a}^{-1} \mathrm{of}$ $\mathbf{N}\left({ }^{15} \mathbf{N}\right.$-depleted) applied eight weeks later. Plants were sampled six times per year to determine $\mathbf{N}$ and ${ }^{15} \mathbf{N}$ content in the plant components throughout the growing season. Soil also was sampled seven times per year to determine inorganic $\mathbf{N}$ concentrations within the four treatments as well as in a bare soil plot. There was a tendency for the unfertilized treatment to have the lowest and for the split- $N$ treatment to have the highest yield in both years. $\mathbf{N}$ application had no significant effect on plant dry weight or total $N$ content in either year. Dry weight accumulation was 5.5 t.ha ${ }^{-1}$ and total $\mathrm{N}$ accumulation was 88 to $96 \mathrm{~kg} \cdot \mathrm{ha}^{-1}$ for aboveground biomass in the fertilized plots in 2001 . Of the total $\mathrm{N}$ present, averaged over 2 years, $17 \%$ was removed in prunings, $12 \%$ was lost through primocane leaf senescence, $13 \%$ was removed through fruit harvest, $30 \%$ remained in the over-wintering plant, and $28 \%$ was considered lost or transported to the roots. Peak fertilizer $\mathbf{N}$-uptake occurred by July for the single $\mathbf{N}$ applications and by September for the last application in the split-N treatment. This uptake accounted for $36 \%$ to $37 \%$ (single applications) and $24 \%$ (last half of split application) of the ${ }^{15} \mathrm{~N}$ applied. Plants receiving the highest single rate of fertilizer took up more fertilizer $\mathrm{N}$ while plants receiving the lower rate took up more $\mathbf{N}$ from the soil and from storage tissues. By midharvest, fertilizer $\mathbf{N}$ was found primarily in the fruit, fruiting laterals, and primocanes $(94 \%)$ for all fertilized treatments; however, the majority of the fertilizer $\mathrm{N}$ applied in the last half of the split application was located in the primocanes $(60 \%)$. Stored fertilizer $\mathrm{N}$ distribution was similar in all fertilized treatments. By the end of the second year, $5 \%$ to $12 \%$ of the fertilizer acquired in 2001 remained in the fertilized plants. Soil nitrate concentrations increased after fertilization to 78.5 $\mathrm{g} \cdot \mathrm{m}^{-3}$, and declined to an average of $35.6 \mathrm{~g} \cdot \mathrm{m}^{-3}$ by fruit harvest. Seasonal soil $\mathrm{N}$ decline was partially attributed to plant uptake; however, leaching and immobilization into the organic fraction may also have contributed to the decline.
\end{abstract}

The Pacific Northwest is one of the major red raspberry (Rubus idaeus L.) producers in the world. In 2002,3.9 $\times 10^{6}$ t of raspberries were harvested from 4860 ha in Oregon and Washington (Oregon Agriculture Statistics Service, 2003). The main raspberry grown in the Pacific Northwest is the floricane-fruiting red raspberry cv. Meeker. Floricane-fruiting red raspberry plants have a biennial top and a perennial root system. First-year shoots (primocanes) develop from either vegetative buds on the roots or from basal buds of second-year canes (floricanes). The primocanes over-winter, and during their second spring, produce fruiting laterals and become floricanes. Both primocanes and floricanes exist simultaneously on a single plant. Floricanes senesce and are removed after harvest.

During the last century, many fertilization trials were conducted to determine optimum nitrogen $(\mathrm{N})$ application rates for red raspberry. Results were highly variable with $\mathrm{N}$ application recommendations ranging from 50 to $340 \mathrm{~kg} \cdot \mathrm{ha}^{-1}$ (Dale, 1989). These studies did not clearly determine the fate of the fertilizer $\mathrm{N}$ in the plant or soil, or how $\mathrm{N}$ was partitioned within the plant.

Received for publication 7 July 2003. Accepted for publication 17 Dec. 2003. This paper is a portion of a thesis submitted for MS degree requirement. The authors wish to acknowledge Gil Buller, Research Assistant at North Willamette Research and Extension Center, and John Hart, Professor, Dept. Crop and Soil Science, OSU for their valuable assistance throughout this project. Funding support from the Northwest Center for Small Fruits Research and the Oregon Raspberry and Blackberry Commission is appreciated.

${ }^{1}$ Former graduate student.

${ }^{2}$ Professor, Dept. of Horticulture and Berry Crops Research Leader NWREC; author to whom reprint requests should be addressed; e-mail strikb@science.o regonstate.edu.

${ }^{3}$ Professor.
Current fertilizer $\mathrm{N}$ recommendations in Oregon are 70 to 90 $\mathrm{kg} \cdot \mathrm{ha}^{-1}$ for established plants depending on crop load, cane vigor, plant age, soil type, and irrigation system (Hart et al., 2000).

Red raspberry is N-limited, especially during periods of rapid growth (Kowalenko et al., 2000). However, over-application of $\mathrm{N}$ fertilizers is costly to the producer and may have negative effects on the environment and plant performance (Tisdale et al., 1999). As a result, characterizing $\mathrm{N}$-cycling within production agriculture, to match fertilizer $\mathrm{N}$ application to plant $\mathrm{N}$ need, is important for both improved production and decreased environmental risk. Research in other perennial crops has revealed the possibility of maintaining production levels while simultaneously reducing fertilizer N inputs (Ledgard et al., 1992; Sanchez et al., 1991).

Plant $\mathrm{N}$ requirements depend on the time of year; therefore, $\mathrm{N}$-partitioning within the plant varies throughout the growing season. Early in the season, blackberry (Rubus sp.) plants preferentially partitioned fertilizer $\mathrm{N}$ to new growth such as primocanes and fruit. At the end of the growing season, the fertilizer $\mathrm{N}$ was stored in roots, crown, and over-wintering primocanes (Malik et al., 1991; Mohadjer et al., 2001; Naraguma et al., 1999). Time of fertilizer application also affects within-plant $\mathrm{N}$ partitioning. In apple (Malus domestica Borkh.) and pear (Pyrus communis L.), ${ }^{15} \mathrm{~N}$ applied late in the season accumulated primarily in storage organs and was subsequently found in new growth the following spring (Khemira et al., 1998; Sanchez et al., 1992). Plant N requirement is also influenced by fertilization history. Under $\mathrm{N}$-deficient circumstances, Taylor and van den Ende (1969) found that peach trees (Prunus persica L.) partitioned storage $\mathrm{N}$ preferentially to reproductive tissues over vegetative growth. 
Because of their $\mathrm{N}$ storage capacity, most mature perennial crops have a lower fertilizer recovery (FR) than those of agronomic crops. For example, mature highbush blueberry plants (Vaccinium corymbosum L.) recovered $32 \%$ of the applied fertilizer by the end of the growing season (Retamales and Hanson, 1989) compared to approximately $50 \%$ for corn (Zea mays L.) (Varvel and Peterson, 1990). However, the amount of fertilizer $\mathrm{N}$ reported as recovered might not provide a complete picture of overall $\mathrm{N}$ use in the plant. Fertilizer $\mathrm{N}$ uptake may impact the uptake and use of other forms of plant-available $\mathrm{N}$, such as storage and soil N (Khemira et al., 1998).

Nitrogen cycling patterns have been studied in blackberry using ${ }^{15} \mathrm{~N}$ (Malik et al., 1991; Mohadjer et al., 2001; Naraguma et al., 1999); however, no work has been done with soil-applied ${ }^{15} \mathrm{~N}$ in red raspberry. Currently, the only ${ }^{15} \mathrm{~N}$ research in red raspberry examined the use of foliar ${ }^{15} \mathrm{~N}$ applied in late summer to primocane-fruiting raspberry (Reickenberg and Pritts, 1996).

The objectives of this study were to 1) determine the effects of $\mathrm{N}$ fertilization rate and timing on $\mathrm{N}$ uptake, partitioning and yield in red raspberry using ${ }^{15} \mathrm{~N}, 2$ ) determine the amount and partitioning of fertilizer $\mathrm{N}$ stored in the plant in the second year, and 3 ) estimate the ability of the soil in a mature summer-bearing red raspberry field to supply $\mathrm{N}$ to the plant.

\section{Materials and Methods}

EXPERIMENTAL SITE AND DESIGN. This study was conducted from 2000-02 in a mature 'Meeker' red raspberry planting (0.13 ha) established in 1993 at the North Willamette Research and Extension Center (NWREC), Oregon State University, Aurora, Ore. The plants were established at $0.75 \mathrm{~m}$ within rows and 3.0 $\mathrm{m}$ between rows on a Quatama series soil (fine-loamy, mixed, mesic Aqualtic Haploxeralfs) having a $5.8 \mathrm{pH}, 143 \mathrm{mg} \cdot \mathrm{kg}^{-1}$ Bray$\mathrm{P}$, and $279 \mathrm{mg} \cdot \mathrm{kg}^{-1} \mathrm{~K}$ (ammonium acetate). The organic matter content was $3 \%$ to $4 \%$. Plants were maintained in a hill system and arc-cane trained as is standard commercial treatment. Each treatment plot was $6.0 \mathrm{~m}$ long with a $3.0 \mathrm{~m}$ unplanted space after each plot to allow for separation by treatment during machine harvest of fruit. The field received overhead irrigation to supply $\approx 2.5 \mathrm{~cm}$ of water per week during the growing season when rainfall was inadequate.

The four treatments in the study differed in rate and timing of $\mathrm{N}$ application: 1) No added $\mathrm{N}(0 \mathrm{~N}) ; 2) 40 \mathrm{~kg} \cdot \mathrm{ha}^{-1}$ of $\mathrm{N}(9$ $\mathrm{g} /$ plant) after budbreak (17 Mar.) $(40 \mathrm{~N}) ; 3) 80 \mathrm{~kg} \cdot \mathrm{ha}^{-1}$ of $\mathrm{N}(18$ $\mathrm{g} /$ plant), on 17 Mar. (80 N); 4) $40 \mathrm{~kg} \cdot \mathrm{ha}^{-1}$ of $\mathrm{N}$ (9 g/plant) on 17 Mar. (unlabeled fertilizer) and $40 \mathrm{~kg} \cdot \mathrm{ha}^{-1}$ of $\mathrm{N}$ (9 g/plant) on 17 May (split-N). All fertilizer was applied in the form of granular ammonium sulfate. Depleted ${ }^{15} \mathrm{~N}$ fertilizer $\left(0.01\right.$ atom percent ${ }^{15} \mathrm{~N}$, Icon Isotopes, Summit, N.J.) was applied in 2001, as described above. In 2002, only unlabeled fertilizer was applied on similar dates and at the same rates as in 2001. Fertilizer was broadcast on the soil surface up to $0.3 \mathrm{~m}$ away on either side of the row. All treatment plots were fertilized with $35 \mathrm{~kg} \cdot \mathrm{ha}^{-1}$ of $\mathrm{P}$ and 66 $\mathrm{kg} \cdot \mathrm{ha}^{-1}$ of $\mathrm{K}$ each spring.

In Spring 2000, six plots within the field were fertilized with 28 $\mathrm{kg} \cdot \mathrm{ha}^{-1}$ of $\mathrm{N}$ (unlabeled) in April plus $16.8 \mathrm{~kg} \cdot \mathrm{ha}^{-1}$ of $\mathrm{N}$ (unlabeled) and $44.8 \mathrm{~kg} \cdot \mathrm{ha}^{-1} \mathrm{~N}$ (1.0 atom percent ${ }^{15} \mathrm{~N}$, Icon Isotopes, Summit, N.J.) in May. These plots were included so that $\mathrm{N}$ storage could be observed over a longer period of time. These plants will be referred to as the enriched plants to differentiate them from the rate and timing treatments.

Plant Sampling AND ANalysis. Throughout 2001 and 2002, a single plant per replication was destructively harvested on each of 12 dates. In 2001 the destructive harvest schedule was as follows: 12 Apr. (1 month after fertilizer application), 14 June (late bloom), 12 July (late fruit maturity), 15 Aug. (floricane senescence), 19 Sept. (before leaf senescence), and 10 Dec. (dormancy). Destructive harvest dates in 2002 followed the same phenological pattern as 2001: 18 Apr., 17 June, 11 July, 15 Aug., 18 Sept., and 10 Dec. Plants were excavated to a depth of up to $0.5 \mathrm{~m}$. The southernmost plant in the plot was always sampled, so as to minimize disturbance of neighboring plants.

On each sampling date, the harvested plants were divided into large roots $(>1 \mathrm{~cm}$ in diameter), small roots $(<1 \mathrm{~cm}$ in diameter), crown, primocanes, primocane leaves, floricanes, fruiting laterals (including leaves), and green fruit (when present). Due to the difficulty of recovering the whole root system without disturbing the neighboring plant and the extensive growth habit of raspberry roots, the amount of root tissue recovered was considered to be a subsample of the entire root system. Roots were hand washed to remove soil. The separated plants were dried at $100{ }^{\circ} \mathrm{C}$ to a constant dry weight, randomly subsampled, and ground to pass a 40-mesh screen. Ground samples were sent to Isotope Services (Los Alamos, N.M.) for analysis of total N concentration and atom percent ${ }^{15} \mathrm{~N}$ by mass spectrometry.

Atom percent values were converted to the proportion of the nitrogen derived from fertilizer (NDFF), using standard conversions (Hauck and Bremner, 1976). The ${ }^{15} \mathrm{~N}$ natural abundance was assumed equal to 0.366 atom percent.

Fresh fruit were harvested every 2 to $3 \mathrm{~d}$ throughout the harvest season using a Littau over-the-row rotary harvester (Littau Harvesters Inc., Stayton, Ore.). On each harvest date, total fresh yield and average berry weight per treatment ( 25 berry subsample per replication per harvest) were recorded. Total yield per plot and per plant were calculated, adjusting for missing plants when necessary. To determine fruit $\mathrm{N}$ content, a 25 berry subsample was collected from an early, middle and late harvest date each year and freeze-dried. The freeze-dried fruit were weighed, ground and analyzed for total $\mathrm{N}$ concentration and atom percent ${ }^{15} \mathrm{~N}$ as described above. Average fruit $\mathrm{N}$ and ${ }^{15} \mathrm{~N}$ concentrations were calculated.

Three single plants per replication from the enriched plots were destructively harvested in 2002 on the same six dates listed above and on 7 Feb. 2002 and 11 Feb. 2003. Plants were divided, dried, ground and analyzed as previously described.

In September 2001 and 2002, the following data on cane growth were collected: the number of plants and primocanes per plot; cane length and cane diameter ( $0.3 \mathrm{~m}$ above ground) on a subsample of three floricanes and three primocanes per plot; the number of fruiting sites and the lateral length of one lateral from each of the apical, middle and basal section of the cane ( $\mathrm{n}=3$ canes/plot); the total number of nodes and nodes with a lateral(s), and percent budbreak ( $\mathrm{n}=3$ canes/plot).

Floricanes were pruned and removed from the field after the September measurements and destructive harvest were completed each year. Primocanes were not suppressed in this study.

To determine the presence of residual ${ }^{15} \mathrm{~N}$ remaining in the field between labeled fertilizer application (2001) and unlabeled fertilizer application (2002), soil was removed from a plot that had received a labeled fertilizer application the previous year. Corn seeds were planted in this soil to act as indicator plants for residual ${ }^{15} \mathrm{~N}$. The plants were grown in the greenhouse for five weeks. The corn was harvested, separated into aboveground portion and roots, dried, weighed, ground, and analyzed for $\mathrm{N}$ 
concentration and atom percent ${ }^{15} \mathrm{~N}$ as previously described for the raspberry plants.

SoIL SAMPLING AND ANALYSIS. Soil samples were taken from each treatment plot from the surface which received fertilizer within two days of each destructive harvest date in order to determine the amount of plant-available soil N. In addition, soil was sampled in March of each year before fertilizer application to establish a baseline amount of soil N. A bare soil plot containing no plants or weeds was also sampled each time. Samples were taken from depths of 0 to $0.15 \mathrm{~m}$ and 0.16 to $0.30 \mathrm{~m}$, on each date. Subsamples $(n=4)$ were taken from within each replication, homogenized, and analyzed at the Central Analytical Lab (Corvallis, Ore.) for ammonium $\left(\mathrm{NH}_{4}-\mathrm{N}\right)$ and nitrate $\left(\mathrm{NO}_{3}-\mathrm{N}\right)$ concentrations.

The soil data were converted from ppm to $\mathrm{g} / \mathrm{sampled}$ volume in order to avoid inflating the amount of inorganic $\mathrm{N}$ reported in the soil. These units more accurately represented the method of fertilizer application since fertilizer was broadcast within the plant row, but was not applied in the alley between plant rows. The conversion from $\mathrm{ppm}$ to $\mathrm{g} / \mathrm{sampled}$ volume was carried out as follows: $\mathrm{g} / \mathrm{sampled}$ volume $=\left[\mathrm{ppm}\left(\mathrm{mg} \cdot \mathrm{kg}^{-1}\right) \times\left(\mathrm{kg} \cdot\left(1 \times 10^{6}\right.\right.\right.$ $\left.\mathrm{mg})^{-1}\right] \times\left[\right.$ soil bulk density $\left.\left(\mathrm{g} \cdot \mathrm{cm}^{-3}\right)\right] \times\left[\right.$ fertilized area $\left(\mathrm{cm}^{2} /\right.$ sample area) $] \times[$ sample depth $(\mathrm{cm})]$.

The bulk density of the soil was determined to be $1.2 \mathrm{~g} \cdot \mathrm{cm}^{-3}$.
The area of fertilization per plant was 0.75 $\mathrm{m}$ by $0.60 \mathrm{~m}$. While the possibility for error remains in this conversion, it provided a more accurate picture of $\mathrm{N}$ in the soil than $\mathrm{kg} \cdot \mathrm{ha}^{-1}$ for this study.

Soil temperatures were measured within the experimental site at two soil depths $(0.15$ and $0.30 \mathrm{~m}$ ) from April 2001 through November 2002 using a four-channel datalogger (Hobo 8K; Onset Computer Corp., Bourne, Mass.). Air temperature and rainfall data were recorded at a weather station less than $1 \mathrm{~km}$ from the plots.

Statistical analyses. The experimental design was completely randomized. The experimental unit was the plot, which was replicated three times. Since plants were not randomly chosen for destructive harvest, sample dates were not independent and analysis was not performed between dates. Treatments were the rates and timing of fertilizer $\mathrm{N}$ application. Analysis of variance was performed for rate and timing effects using the GLM procedure in SAS (SAS Institute Inc., 1999). Treatment means were compared using a Fisher's protected least significant difference (LSD) test. Contrasts were also performed in SAS (SAS Institute Inc., 1999) to separate the effects of rate and timing for those plots receiving $\mathrm{N}$ fertilizer.

Fig. 1. (A) Dry weight content and (B) total N content pooled across all treatments for 'Meeker' red raspberry plants excavated in April through December 2001 and 2002. Aboveground plant included all tissues except roots. Floricanes included fruiting laterals, canes, and green and red fruit (when present). Primocanes included canes and leaves. Floricanes were removed annually in late September. Bars indicate standard deviation of the mean $(n=3)$.

\section{Results and Discussion}

DRY WEIGHT ACCUMULATION. No significant differences were found in total plant dry weight content or partitioning among treatments in 2001 or 2002, so dry weight values are pooled across treatments in Fig. 1A. In 2001, whole plant dry weight (excluding roots) increased from $608 \mathrm{~g} /$ plant in April (1 month after Napplication) to a maximum of $1676 \mathrm{~g} / \mathrm{plant}$ in July (midharvest), and then declined throughout the remainder of the growing season (Fig. 1A). This dry weight accumulation $\left(5.5 \mathrm{t} \cdot \mathrm{ha}^{-1}\right)$, the initial spring value subtracted from the maximum level attained, is consistent with previous research in red raspberry (Dean et al., 2000; Kowalenko, 1994; Wright and Waister, 1980). In 2002, the first destructive harvest occurred after early spring growth had begun, thereby missing a period of initial growth. As a result, by the first sampling in 2002, pooled floricane dry weights were approximately double the values observed at the end of the first year (Fig. 1A). Aboveground plant dry weight then declined from midharvest through December 2002 as in the previous year. Red raspberry seasonal growth patterns are influenced by differences in temperature and precipitation (Kowalenko, 1994). In the present study, temperatures and precipitation during Spring 2002 were higher than in 2001 (data not shown).
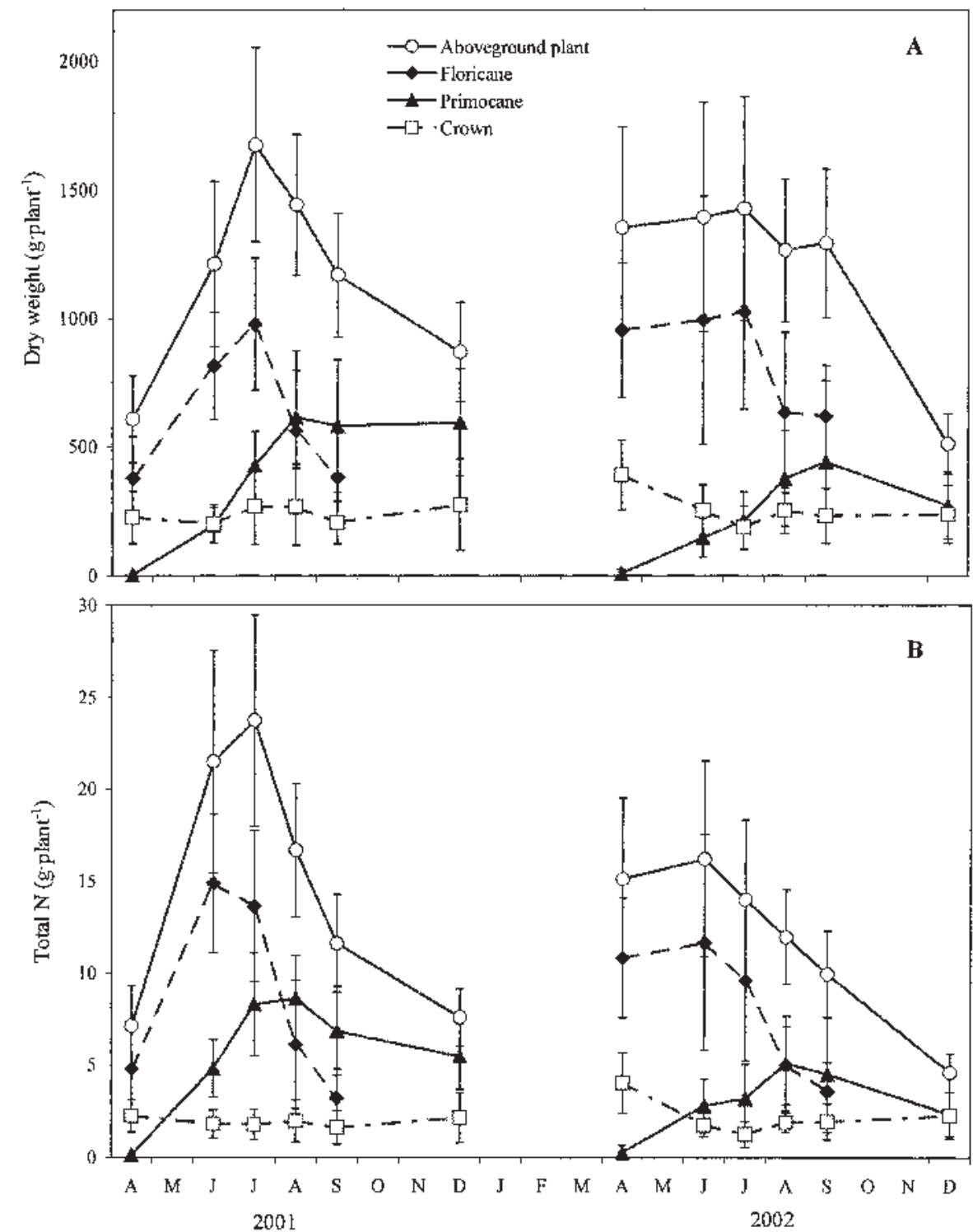
Floricane tissues increased in dry weight early in the growing season and then declined; an average of $44 \%$ of primocane dry weight was acquired after midharvest (July sampling). Crown dry weight varied little over time (Fig. 1A). Dry matter accumulation in roots is not shown since only a portion of the root system was sampled.

Nitrogen accumulation. Total N content (Fig. 1B) was pooled across treatments, as there were generally no significant differences among treatments on a whole plant basis (excluding roots) in either year. Plant size varied within treatments, explaining most of the variability in total $\mathrm{N}$ among treatments. However, a trend was observed $(p=0.14)$ where less $\mathrm{N}$ accumulated in the $0 \mathrm{~N}$ treatment ( $55 \mathrm{~kg} \cdot \mathrm{ha}^{-1}$ of $\mathrm{N}$ ) than in fertilized plots (88 to 96 $\mathrm{kg} \cdot \mathrm{ha}^{-1}$ of $\mathrm{N}$ ) in 2001. $\mathrm{N}$ accumulation in aboveground biomass for fertilized plots in 2001 was consistent with previous research in red raspberry (Dean et al., 2000; Kowalenko, 1994; Wright and Waister, 1980). Since early growth in 2002 was not sampled, $\mathrm{N}$ accumulation was not calculated for the second year of the study. Patterns of $\mathrm{N}$ accumulation were similar to dry matter accumulation with regard to differences between years previously described (Fig. 1B).

Raspberries have lower dry weight and $\mathrm{N}$ accumulation values on a $\mathrm{kg} \cdot \mathrm{ha}^{-1}$ basis than other perennial crops (Dean et al., 2000; Mohadjer et al., 2001). This is partially attributed to the wide inter-row spacings required for machine harvest. The average cumulative dry-matter yield of 'Meeker' red raspberry fruit in this study (Table 1) and 'Willamette' red raspberry fruit in a previous study (Kowalenko, 1994) was $\approx 0.3 \mathrm{~kg} /$ plant. Nitrogen removal in fruit averaged $3.2 \mathrm{~g} /$ plant (Table 1) in both this study and in 'Willamette' red raspberry (Kowalenko, 1994). Annual total N accumulation (excluding roots) was $16 \mathrm{~g} /$ plant (Fig. 1B) in this study and $19 \mathrm{~g} /$ plant in 'Willamette' red raspberry (Kowalenko, 1994). This lower fruit yield and $\mathrm{N}$ content suggests a reduced $\mathrm{N}$ requirement for raspberry plants in comparison to other perennial crops.

Of the total $\mathrm{N}$ present, averaged over both years in the fertilized treatments, $17 \%$ was removed in September prunings,
$12 \%$ fell to the ground due to primocane leaf senescence, $13 \%$ was accounted for in harvested fruit, $30 \%$ remained in the over wintering plant, and $28 \%$ was considered lost or transported to the roots (Table 2 ). Average total $\mathrm{N}$ removed from the field was $\approx 40 \mathrm{~kg} \cdot \mathrm{ha}^{-1} \cdot \mathrm{yr}^{-1}$ of $\mathrm{N}$.

Floricane removal, or pruning, in a commercial field typically occurs any time after harvest throughout the fall. Less plant $\mathrm{N}$ is available to be remobilized if the floricanes are removed too early. In this study, average $\mathrm{N}$ losses through floricane removal were $25.6 \mathrm{~kg} \cdot \mathrm{ha}^{-1}$ of $\mathrm{N}$ if pruning was performed in mid-August (Table 2). However, if pruning was done in mid-September, allowing more time for floricane $\mathrm{N}$ to be remobilized to storage tissues, losses were reduced to $15.5 \mathrm{~kg} \cdot \mathrm{ha}^{-1}$ of $\mathrm{N}$ (Table 2). Pruned floricanes were removed from the field in this study; however, growers typically flail the prunings in the field, thereby returning some of the $\mathrm{N}$ to the soil through decomposition. A portion of the $\mathrm{N}$ in prunings returned to the system may be available for future use. Nine percent of the ${ }^{15} \mathrm{~N}$ in kiwifruit (Actinidia deliciosa 'Hayward') prunings was recovered by the plants within 2 years (Ledgard et al., 1992).

In general, no significant differences were observed among treatments in the percentage of total $\mathrm{N}$ present in a given tissue ( $\mathrm{N}$ partitioning) in 2001 or 2002 (data not shown). Total $\mathrm{N}$ and dry weight were partitioned differently. While N-partitioning was similar to dry weight partitioning in April and December, once leaf growth commenced, fruiting laterals and primocane leaves had a higher percentage of total plant $\mathrm{N}$ than their percentage of whole plant dry weight. $\mathrm{N}$ was exported from the crown and floricanes throughout the growing season. Most of this $\mathrm{N}$ was remobilized to the fruiting laterals in June. The percentage of total $\mathrm{N}$ partitioned to floricanes declined from $55 \%$ and $50 \%$ in April, to $10 \%$ and $26 \%$ in September 2001 and 2002, respectively. In June, fruiting laterals accounted for $50 \%$ of the total $\mathrm{N}$ in 2001 and $42 \%$ in 2002. As floricanes senesced through September, primocanes and primocane leaves received remobilized N. In August, primocane leaves accounted for $32 \%$ of the total $\mathrm{N}$ in 2001 and $25 \%$ in 2002. Primocanes comprised $31 \%$ and $28 \%$ of

Table 1. Effect of nitrogen fertilizer application on yield per plant, nitrogen partitioning to fruit, and primocane length and number of 'Meeker' red raspberry.

\begin{tabular}{|c|c|c|c|c|c|c|c|}
\hline Treatment $^{z}$ & $\begin{array}{c}\text { Total } \\
\text { fresh } \\
\text { yield } \\
\text { (kg/plant) }\end{array}$ & $\begin{array}{c}\text { Yield } \\
\text { dry wt } \\
\text { (g/plant) }\end{array}$ & $\begin{array}{c}\text { Fruit } \\
\text { wt } \\
(\mathrm{g})\end{array}$ & $\begin{array}{c}\text { Fruit } \\
\mathrm{Ny}^{\mathrm{y}} \\
(\%)\end{array}$ & $\begin{array}{c}\text { Fruit } \\
\text { NDFFy } \\
(\%)\end{array}$ & $\begin{array}{c}\text { Primocane } \\
\text { length } \\
(\mathrm{cm})\end{array}$ & $\begin{array}{c}\text { Primocanes/ } \\
\text { plot }^{\mathrm{x}} \\
\text { (no.) }\end{array}$ \\
\hline \multicolumn{8}{|l|}{2001} \\
\hline $0 \mathrm{~N}$ & 1.4 & 230 & $2.5 \mathrm{a}^{\mathrm{w}}$ & $1.03 \mathrm{a}$ & NA & 296 & 129.7 \\
\hline $40 \mathrm{~N}$ & 1.7 & 263 & $2.7 \mathrm{bc}$ & $1.04 \mathrm{a}$ & $9.2 \mathrm{a}$ & 320 & 119.3 \\
\hline $80 \mathrm{~N}$ & 1.9 & 312 & $2.6 \mathrm{ac}$ & $1.43 \mathrm{~b}$ & $29.4 \mathrm{~b}$ & 325 & 126.0 \\
\hline Split-N & 2.2 & 359 & $2.7 \mathrm{bc}$ & $1.06 \mathrm{a}$ & $5.0 \mathrm{a}$ & 345 & 174.7 \\
\hline$p$ value & 0.16 & 0.14 & 0.02 & 0.00 & 0.00 & 0.34 & 0.17 \\
\hline \multicolumn{8}{|l|}{2002} \\
\hline $0 \mathrm{~N}$ & $1.0 \mathrm{a}$ & $181 \mathrm{a}$ & $2.1 \mathrm{a}$ & $0.53 \mathrm{a}$ & NA & $224 a$ & 45.7 \\
\hline $40 \mathrm{~N}$ & $1.1 \mathrm{a}$ & $218 \mathrm{a}$ & $2.2 \mathrm{~b}$ & $0.63 \mathrm{~b}$ & $3.5 \mathrm{a}$ & $281 \mathrm{~b}$ & 48.7 \\
\hline $80 \mathrm{~N}$ & $1.4 \mathrm{a}$ & $251 \mathrm{a}$ & $2.3 \mathrm{~b}$ & $0.74 \mathrm{c}$ & $7.7 \mathrm{~b}$ & $297 \mathrm{~b}$ & 54.3 \\
\hline Split-N & $2.1 \mathrm{~b}$ & $388 \mathrm{~b}$ & $2.3 \mathrm{~b}$ & $0.92 \mathrm{~d}$ & $4.2 \mathrm{a}$ & $303 \mathrm{~b}$ & 58.3 \\
\hline$p$ value & 0.03 & 0.03 & 0.02 & 0.00 & 0.00 & 0.00 & 0.68 \\
\hline
\end{tabular}

zTreatments applied were $0 \mathrm{~kg} \cdot \mathrm{ha}^{-1}$ of $\mathrm{N}(0 \mathrm{~N}) ; 40 \mathrm{~kg} \cdot \mathrm{ha}^{-1}$ of $\mathrm{N}(40 \mathrm{~N})$ in March (labeled in 2001); $80 \mathrm{~kg} \cdot \mathrm{ha}{ }^{-1}$ of $\mathrm{N}(80 \mathrm{~N})$ in March (labeled in 2001); and $40 \mathrm{~kg} \cdot \mathrm{ha}^{-1}$ of $\mathrm{N}$ in March (unlabeled) plus $40 \mathrm{~kg} \cdot \mathrm{ha}^{-1}$ of $\mathrm{N}$ (split-N) in May (labeled in 2001). The same rates and timings of unlabeled $\mathrm{N}$ were applied in 2002.

y Average for three sample dates - early, middle and late harvest. NDFF = nitrogen derived from fertilizer. Percent $\mathrm{N}$ based on dry weight.

xSix destructive harvests took place between the 2001 and 2002 measurements, thus there were fewer canes in 2002.

wMeans followed by the same letter within years were not significantly different (ANOVA, Fisher's LSD, $P>0.05$ ). 
the total N in September 2001 and 2002, respectively. Fourteen percent of the total $\mathrm{N}$ was partitioned to the harvested red fruit in both years.

Nitrogen concentration in large and small roots ranged from $0.56 \%$ to $2.06 \% \mathrm{~N}$ throughout 2001 and 2002. N concentration in large roots decreased to an average low of $0.83 \% \mathrm{~N}$ during fruiting in 2001, then increased after harvest to a high of $1.45 \%$ $\mathrm{N}$ in December 2001. Trends were similar in 2002. Small roots in the $0 \mathrm{~N}$ treatment had a significantly lower $\mathrm{N}$ concentration than small roots in the $80 \mathrm{~N}$ treatment from August to Decem-

Table 2. An accounting of the total $\mathrm{N}$ in $\mathrm{g} / \mathrm{plant}$ in 'Meeker' red raspberry over 2 years.

\begin{tabular}{|c|c|c|c|c|c|c|}
\hline \multirow[b]{2}{*}{ Treatment ${ }^{z}$} & \multicolumn{6}{|c|}{$\begin{array}{c}\text { Total N } \\
\text { (g/plant) }\end{array}$} \\
\hline & $\begin{array}{c}\mathrm{N} \\
\text { accounted } \\
\text { for }^{\mathrm{y}} \\
\end{array}$ & $\begin{array}{c}\text { Harvested } \\
\text { fruit }^{x}\end{array}$ & Prunings $^{w}$ & $\begin{array}{c}\text { Primocane } \\
\text { leaf } \\
\text { senescence }^{\mathrm{v}}\end{array}$ & $\begin{array}{c}\text { Overwintering } \\
\text { plant }^{\mathrm{u}}\end{array}$ & $\begin{array}{c}\text { Transported } \\
\text { to roots } \\
\text { or lost }{ }^{t}\end{array}$ \\
\hline \multicolumn{7}{|l|}{$\overline{2001}$} \\
\hline $0 \mathrm{~N}$ & & $2.4 \mathrm{a}^{\mathrm{s}}$ & $3.7(8.5)$ & 2.9 & 9.2 & 6.0 \\
\hline $40 \mathrm{~N}$ & & $2.7 \mathrm{ac}$ & $2.6(6.1)$ & 2.7 & 5.3 & 11.6 \\
\hline $80 \mathrm{~N}$ & & $4.7 \mathrm{~b}$ & $1.9(3.0)$ & 2.7 & 6.9 & 11.4 \\
\hline Split-N & & $3.8 \mathrm{bc}$ & $4.5(6.9)$ & 4.8 & 8.4 & 8.3 \\
\hline$p$ value & & 0.02 & $0.21(0.30)$ & 0.22 & 0.69 & 0.66 \\
\hline \multicolumn{7}{|l|}{2002} \\
\hline $0 \mathrm{~N}$ & 11.2 & $1.0 \mathrm{a}$ & $2.2(5.5)$ & 0.9 & 3.5 & 10.1 \\
\hline $40 \mathrm{~N}$ & 13.5 & $1.2 \mathrm{a}$ & $4.2(2.6)$ & 2.0 & 3.5 & 11.1 \\
\hline $80 \mathrm{~N}$ & 10.8 & $1.8 \mathrm{a}$ & $4.3(6.0)$ & 2.3 & 5.7 & 5.3 \\
\hline Split-N & 10.5 & $3.7 \mathrm{~b}$ & $3.5(5.8)$ & 1.6 & 5.4 & 13.0 \\
\hline$p$ value & 0.79 & 0.00 & $0.38(0.17)$ & 0.59 & 0.50 & 0.10 \\
\hline
\end{tabular}

zTreatments applied were $0 \mathrm{~g} /$ plant of $\mathrm{N}(0 \mathrm{~N}) ; 9 \mathrm{~g} /$ plant of $\mathrm{N}(40 \mathrm{~N})$ in March (labeled in 2001); $18 \mathrm{~g} / \mathrm{plant}$ of $\mathrm{N}(80 \mathrm{~N})$ in March (labeled in 2001); and $9 \mathrm{~g} /$ plant of $\mathrm{N}$ in March (unlabeled) plus $9 \mathrm{~g} /$ plant of $\mathrm{N}$ (split-N) in May (labeled in 2001). The same rates and timings of unlabeled $\mathrm{N}$ were applied in 2002.

${ }^{y} \mathrm{~N}$ accounted for indicates the amount of $\mathrm{N}$ measured in the crown and floricane in April 2002.

xRed fruit total $\mathrm{N}$ based on the cumulative season's harvest.

wFloricane and fruiting lateral tissue removed in either September or August (in parentheses).

vAn estimate based on the primocane leaves sampled in September.

"An estimate based on the primocane and crown sampled in December.

'The roots collected represented a subsample of the entire root system; therefore, their total $\mathrm{N}$ content was not known.

sMeans followed by the same letter within year were not significantly different (ANOVA, Fisher's LSD, $P>0.05$ ).

Table 3. An accounting of the nitrogen derived from fertilizer (NDFF) in g/plant in 'Meeker' red raspberry over 2 years.

\begin{tabular}{|c|c|c|c|c|c|c|}
\hline \multirow[b]{2}{*}{ Treatment ${ }^{z}$} & \multicolumn{6}{|c|}{$\begin{array}{c}\text { NDFF } \\
\text { (g/plant) }\end{array}$} \\
\hline & $\begin{array}{c}\mathrm{N} \\
\text { accounted } \\
\text { for }^{\mathrm{y}}\end{array}$ & $\begin{array}{l}\text { Harvested } \\
\text { fruit }^{x}\end{array}$ & Pruningsw & $\begin{array}{c}\text { Primocane } \\
\text { leaf } \\
\text { senescence }^{v}\end{array}$ & $\begin{array}{c}\text { Overwintering } \\
\text { plant }^{u}\end{array}$ & $\begin{array}{c}\text { Transported } \\
\text { to roots } \\
\text { or lost } t^{t}\end{array}$ \\
\hline \multicolumn{7}{|l|}{2001} \\
\hline $40 \mathrm{~N}$ & & $0.25 \mathrm{a}^{\mathrm{s}}$ & $0.32(0.85)$ & $0.47 \mathrm{a}$ & 0.90 & 1.42 \\
\hline $80 \mathrm{~N}$ & & $1.31 \mathrm{~b}$ & $0.53(0.88)$ & $1.07 \mathrm{~b}$ & 1.80 & 1.79 \\
\hline Split-N & & $0.19 \mathrm{a}$ & $0.34(0.25)$ & $0.74 \mathrm{ab}$ & 0.77 & 0.12 \\
\hline$p$ value & & 0.00 & $0.28(0.36)$ & 0.02 & 0.24 & --- \\
\hline \multicolumn{7}{|l|}{2002} \\
\hline $40 \mathrm{~N}$ & 0.96 & $0.048 \mathrm{a}$ & $0.42(0.18 a)$ & 0.040 & $0.088 \mathrm{a}$ & 0.65 \\
\hline $80 \mathrm{~N}$ & 1.74 & $0.14 \mathrm{~b}$ & $0.57(1.05 \mathrm{~b})$ & 0.072 & $0.33 \mathrm{~b}$ & 1.26 \\
\hline Split-N & 0.47 & $0.15 \mathrm{~b}$ & $0.36(0.43 a)$ & 0.049 & $0.19 a b$ & 0.44 \\
\hline$p$ value & 0.20 & 0.00 & $0.73(0.00)$ & 0.10 & 0.02 & --- \\
\hline
\end{tabular}

zTreatments applied were $0 \mathrm{~g} /$ plant of $\mathrm{N}(0 \mathrm{~N}) ; 9 \mathrm{~g} /$ plant of $\mathrm{N}(40 \mathrm{~N})$ in March (labeled in 2001); $18 \mathrm{~g} / \mathrm{plant}$ of $\mathrm{N}(80 \mathrm{~N})$ in March (labeled in 2001); and $9 \mathrm{~g} /$ plant of $\mathrm{N}$ in March (unlabeled) plus $9 \mathrm{~g} /$ plant of $\mathrm{N}$ (split-N) in May (labeled in 2001). The same rates and timings of unlabeled $\mathrm{N}$ were applied in 2002.

yNDFF accounted for indicates the amount of NDFF measured in the crown and floricane in April 2002.

xRed fruit NDFF based on the cumulative season's harvest.

wFloricane and fruiting lateral tissue removed in either September or August (in parentheses).

vAn estimate based on the primocane leaves sampled in September.

"An estimate based on the primocane and crown sampled in December.

The roots collected represented a subsample of the entire root system; therefore, their NDFF content was not known. Data were calculated by subtracting all NDFF removed from the peak NDFF value during the season.

sMeans followed by the same letter within year were not significantly different (ANOVA, Fisher's LSD, $P>0.05$ ). 
ber 2001, and from June to September 2002. In addition, the $\mathrm{N}$ concentration in primocane leaves sampled in August in the 0 $\mathrm{N}$ treatment $(2.28 \% \mathrm{~N})$ was significantly lower than that in the higher $\mathrm{N}$ treatments $(80 \mathrm{~N}$ and split- $\mathrm{N}$; average of $3.01 \% \mathrm{~N})$ in both years. In 2002, the mid-August $\mathrm{N}$ concentration in the $0 \mathrm{~N}$ primocane leaves $(2.21 \% \mathrm{~N})$ fell below recommended concentrations (2.3 to $3.0 \% \mathrm{~N}$ ) (Hart et al., 2000) revealing an overall decline in plant health for the $0 \mathrm{~N}$ treatment.

UPTAKe OF FERTILIZER N-Year 1 . The effect of $\mathrm{N}$ application rate $(40 \mathrm{~N}$ vs. $80 \mathrm{~N})$ on fertilizer $\mathrm{N}$ - uptake was significant on a whole plant basis (excluding roots) in June and September only (data not shown). However, the $80 \mathrm{~N}$ treatment generally contained at least a $67 \%$ higher mass of nitrogen derived from
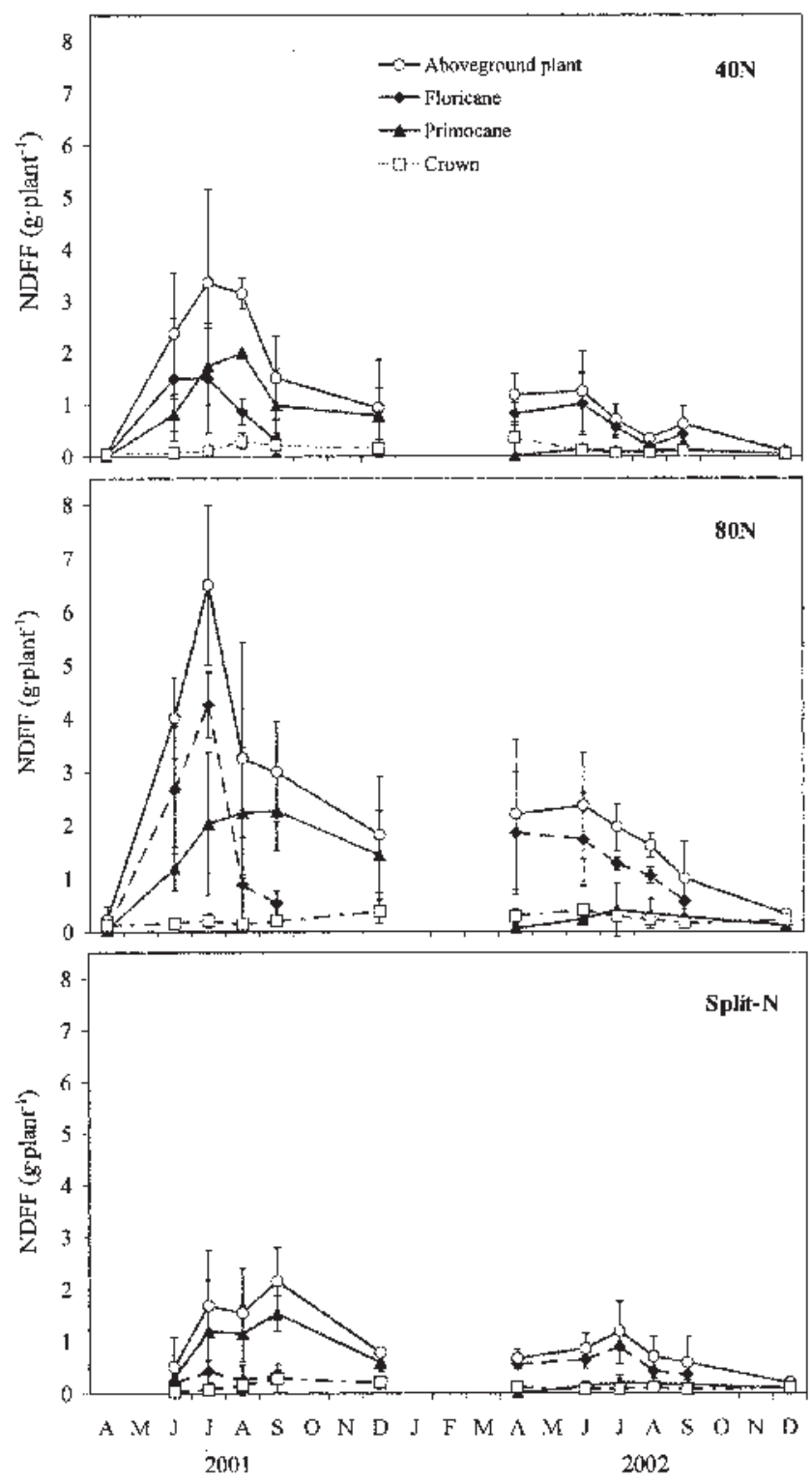

Fig. 2. Nitrogen derived from fertilizer (NDFF) content from April through December 2001 and 2002 for three labeled fertilizer applications: (A) $40 \mathrm{~kg} \cdot \mathrm{ha}^{-1}$ of $\mathrm{N}(40 \mathrm{~N}),\left(\right.$ B) $80 \mathrm{~kg} \cdot \mathrm{ha}^{-1}$ of $\mathrm{N}(80 \mathrm{~N})$, and (C) $40 \mathrm{~kg} \cdot \mathrm{ha}^{-1}$ of N unlabeled fertilizer in March plus $40 \mathrm{~kg} \cdot \mathrm{ha}^{-1}$ of $\mathrm{N}$ labeled fertilizer in May (split-N). Aboveground plant included all tissues except roots. Floricanes included cane, fruiting laterals, and green and red fruit (when present). Primocanes included canes and leaves. Floricanes were removed annually in September. Bars indicate standard deviation of the mean $(n=3)$. fertilizer (NDFF) than the $40 \mathrm{~N}$ treatment throughout the fruiting season. Greater uptake in both primocane and floricane tissues accounted for the higher mass of NDFF in the $80 \mathrm{~N}$ treatment in June. In September, the difference was due to a higher mass of NDFF in primocane tissues in the $80 \mathrm{~N}$ than in the $40 \mathrm{~N}$ treatment (Table 3). Peak NDFF accumulation for the $80 \mathrm{~N}$ treatment occurred in July at $6.50 \mathrm{~g} / \mathrm{plant}$ (Fig. 2A). NDFF uptake for the 80 $\mathrm{N}$ treatment was rapid from April to July, then declined through December.

Research in blueberry has shown that split $\mathrm{N}$ applications resulted in a $10 \%$ higher yield by providing $\mathrm{N}$ when plant growth was highest, thereby improving fertilizer recovery (Retamales and Hanson, 1992). However, yield in kiwifruit was not affected by a split vs. a single application of N (Ledgard et al., 1992). Research in British Columbia indicated that the main flush of growth in red raspberry occurs early in floricanes; therefore, yields may be highest with a single early $\mathrm{N}$ application (Kowalenko et al., 2000).

In this study, few significant differences were seen in fertilizer $\mathrm{N}$ uptake between timing treatments ( $40 \mathrm{~N}$ vs. split-N); however, whole plant NDFF accumulation (excluding roots) during June was significantly higher for the $40 \mathrm{~N}$ vs. the split-N treatment, where $40 \mathrm{~kg} \cdot \mathrm{ha}^{-1}$ of labeled $\mathrm{N}$ was applied later in the season. The $\%$ NDFF (the percentage of total $\mathrm{N}$ that came from labeled fertilizer) in split-N roots was lower than the percentage in 40 $\mathrm{N}$ roots, suggesting that the later $\mathrm{N}$ application did not increase NDFF content in storage tissues as occurs in late $\mathrm{N}$ applications in fruit trees (Khemira et al., 1998; Sanchez et al., 1992). The 40 $\mathrm{N}$ treatment accumulated 4.5 times as much fertilizer $\mathrm{N}$ as the split-N treatment in June. Most of this difference was reflected in fertilizer $\mathrm{N}$-uptake in new growth (fruiting laterals, green fruit, primocanes, and primocane leaves); the $40 \mathrm{~N}$ treatment accumulated $2.24 \mathrm{~g} /$ plant of fertilizer $\mathrm{N}$ in new growth vs. $0.47 \mathrm{~g} /$ plant in new growth for the split-N treatment by June. However, in the split-N treatment the labeled fertilizer had only been applied in May and there was less time for plant uptake, whereas the single $40 \mathrm{~N}$ treatment was applied in March.

Peak NDFF accumulation occurred in July at $3.35 \mathrm{~g} /$ plant for the $40 \mathrm{~N}$ treatment (Fig. 2B). NDFF accumulation was most rapid for the $40 \mathrm{~N}$ treatment between April and July, uptake plateaued in August, then declined in September and December. Peak fertilizer $\mathrm{N}$ accumulation for the split-N treatment was in September at $2.16 \mathrm{~g} /$ plant (Fig. 2C). NDFF accumulation was most rapid for the split-N treatment from June to July, increased again from August to September, and declined in December.

Little labeled fertilizer $\mathrm{N}$ was partitioned to floricane tissues with the May application (split-N) in 2001, but rather went to primocane growth. However, the NDFF content in the primocane tissues of split-N plants was not different from that of $40 \mathrm{~N}$ plants. Since the split-N treatment also received unlabeled fertilizer in March, the March fertilizer $\mathrm{N}$ may have already fulfilled the $\mathrm{N}$ needs of the current year's floricane tissues.

Initial fertilizer $\mathrm{N}$-uptake was low for all treatments; at the first sampling the fertilizer $\mathrm{N}$ that was taken up was primarily present in the crown. In June, the fruiting laterals were the main sink for fertilizer $\mathrm{N}$ for both the $40 \mathrm{~N}$ and the $80 \mathrm{~N}$ treatments. In the split-N treatment, much of the May-applied fertilizer $\mathrm{N}$ was allocated to the primocane leaves in June. In July, fruiting tissues were still an important sink for fertilizer $\mathrm{N}$, especially for the $80 \mathrm{~N}$ treatment (Table 3); however, allocation of fertilizer $\mathrm{N}$ to primocane tissues was increasing. Fertilizer $\mathrm{N}$ in primocanes continued to increase through leaf senescence. Floricanes took 


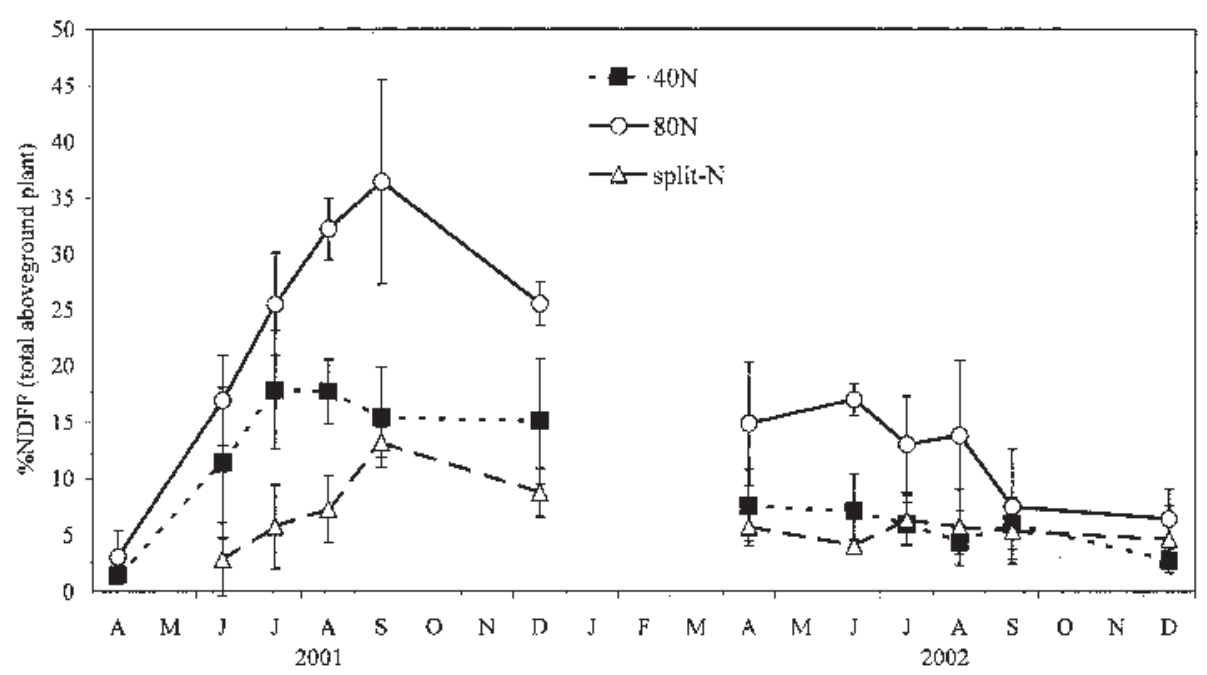

Fig. 3. Percentage of $\mathrm{N}$ derived from the fertilizer (NDFF) of aboveground plants in April through December 2001 and 2002 for three labeled fertilizer applications, $40 \mathrm{~kg} \cdot \mathrm{ha}^{-1}$ of $\mathrm{N}(40 \mathrm{~N}), 80 \mathrm{~kg} \cdot \mathrm{ha}^{-1}$ of $\mathrm{N}(80 \mathrm{~N})$, and $40 \mathrm{~kg} \cdot \mathrm{ha}^{-1}$ of $\mathrm{N}$ unlabeled fertilizer in March plus $40 \mathrm{~kg} \cdot \mathrm{ha}^{-1}$ of $\mathrm{N}$ labeled fertilizer in May $($ split-N). Bars indicate standard deviation of the mean $(n=3)$.

up little fertilizer $\mathrm{N}$, especially from the last half of the split-N treatment (Fig. 2C).

Labeled fertilizer $\mathrm{N}$-uptake was low compared to blackberry (Mohadjer et al., 2001) and other perennial crops (Feigenbaum et al., 1987; Khemira et al., 1998). During the on-year in 'Kotata' trailing blackberry, the maximum NDFF content was $13.9 \mathrm{~g} / \mathrm{plant}$ (excluding roots) (Mohadjer et al., 2001). In the current study, maximum fertilizer $\mathrm{N}$-uptake was $6.5 \mathrm{~g}$ /plant (excluding roots). This difference can probably be attributed to raspberry's smaller plant size and lower yield compared to these other crops.

When fertilizer $\mathrm{N}$ was considered as a percentage of total $\mathrm{N}$ in the plant, $\%$ NDFF averaged $18 \%$ and $26 \%$ at peak growth (July) for the $40 \mathrm{~N}$ and $80 \mathrm{~N}$ treatments, respectively. By September, when primocane growth neared its peak, the $80 \mathrm{~N}$ treatment averaged $36 \%$ NDFF on a whole plant basis, and the split-N and $40 \mathrm{~N}$ treatments had $13 \%$ and $15 \% \mathrm{NDFF}$, respectively. In blackberry, when fertilizer was applied in the on-year, \%NDFF averaged 24\% in July (Mohadjer et al., 2001). So while fertilizer $\mathrm{N}$-uptake was lower than in other perennial crops, the relative amount of fertilizer $\mathrm{N}$ within the plant was similar and increased with increasing $\mathrm{N}$ application rate.

The $80 \mathrm{~N}$ plants took up more fertilizer $\mathrm{N}$ than did the $40 \mathrm{~N}$ and split-N plants, often containing between $67 \%$ to $100 \%$ more $\%$ NDFF than the $40 \mathrm{~N}$ plants on a whole plant basis (Fig. 3). Red fruit in the $80 \mathrm{~N}$ treatment contained three times more \% NDFF than red fruit in any other treatment (Table 1). By December, the $80 \mathrm{~N}$ treatment had the highest \% NDFF in storage tissues of any treatment, at which point, the small roots of the $40 \mathrm{~N}, 80$ $\mathrm{N}$, and split-N treatments contained $20 \%, 29 \%$, and $12 \%$ NDFF, respectively.

Even though the $80 \mathrm{~N}$ plants had a much higher \%NDFF than the $40 \mathrm{~N}$ plants, total $\mathrm{N}$ uptake was similar. For example, the average $\%$ NDFF from August to December 2001 was $16 \%$ for 40 $\mathrm{N}$ plants and $31 \%$ for $80 \mathrm{~N}$ plants, while average total $\mathrm{N}$ content in this period was $12.2 \mathrm{~g} / \mathrm{plant}$ for $40 \mathrm{~N}$ plants and $9.0 \mathrm{~g} / \mathrm{plant}$ for $80 \mathrm{~N}$ plants. This indicates that the high $\% \mathrm{NDFF}$ in the 80 $\mathrm{N}$ plants was luxury uptake in a $\mathrm{N}$ saturated system. Uptake of fertilizer $\mathrm{N}$ simply replaced soil $\mathrm{N}$ that would have been taken up otherwise. This plant strategy has also been observed in kiwifruit; when additional fertilizer $\mathrm{N}$ was added, soil N-uptake was reduced (Ledgard and Smith, 1992).

Labeled fertilizer $\mathrm{N}$ recovery at peak NDFF accumulation was 37\%, 36\%, and $24 \%$ for the $40 \mathrm{~N}, 80 \mathrm{~N}$, and split-N treatments, respectively. Since our N accounting does not include $\mathrm{N}$ in roots, actual fertilizer recovery was likely higher. For the $40 \mathrm{~N}$ treatment in July, 32\% of the fertilizer recovered was found in the floricane tissues, $52 \%$ was in the primocane tissues, and $8 \%$ was in the red fruit. In July, at the $80 \mathrm{~N}$ treatment's peak NDFF accumulation, $38 \%$ of the fertilizer recovered was found in the floricane tissues, $31 \%$ was in the primocane tissues, and $20 \%$ was in red fruit. The split-N treatment's peak NDFF uptake was in September at which point primocane tissues contained $71 \%$ of the fertilizer recovered.

Fertilizer $\mathrm{N}$ recovery, as a percentage of the ${ }^{15} \mathrm{~N}$ added, was similar to other small fruit crops. Recovery was $32 \%$ to $45 \%$ in blackberry (Mohadjer et al., 2001; Naraguma et al., 1999) and $32 \%$ in mature highbush blueberry (Retamales and Hanson, 1989). The lower fertilizer recovery and N-uptake for perennial crops (compared to agronomic crops) can be attributed to plant size and subsequent $\mathrm{N}$ need, the amount of labile $\mathrm{N}$ available in the soil, and the presence of storage $\mathrm{N}$ already in the plant.

Corn grown in ${ }^{15} \mathrm{~N}$-labeled soil the year after labeled fertilizer application contained $<0.9 \% \mathrm{NDFF}$. Therefore, it was assumed, based on these data and previous work at this experimental site (Mohadjer et al., 2001), that the uptake of residual labeled fertilizer in the second year was minimal. In addition, ${ }^{15} \mathrm{~N}$ was not found in the $0 \mathrm{~N}$ treatment plants; therefore, it was concluded that roots from adjacent plots had not overlapped.

STORED FERTILIZER N-Year 2. Little loss was seen in NDFF content between dormancy and budbreak (Fig. 2; Table 3) indicating the labeled $\mathrm{N}$ was conserved during this period. Although total labeled $\mathrm{N}$ in the roots was not quantified, the \%NDFF in roots did not change over the dormant season (data not shown). This suggests that little fertilizer $\mathrm{N}$ was reallocated from the roots to the crown and floricanes during this time. Stored fertilizer N distribution was similar in all three treatments (Fig. 2). NDFF content slowly declined throughout the 2002 growing season to a low of 0.1 to $0.3 \mathrm{~g} /$ plant (Table 3 ). By December 2002, $4 \%$ of the NDFF acquired in 2001 remained in the $40 \mathrm{~N}$ treatment, $7 \%$ remained in the $80 \mathrm{~N}$ treatment, and $8 \%$ remained in the split-N treatment (Table 3).

Stored plant $\mathrm{N}$ is an important resource for perennial plant growth in the spring. In our study, $24 \%$ to $37 \%$ of the $\mathrm{N}$ in new growth came from the fertilizer. Therefore, the remaining $\mathrm{N}$ is derived from soil mineralization and plant reserves. Sixty percent of the $\mathrm{N}$ present in new growth in kiwifruit was from remobilization of $\mathrm{N}$ stored in the vines (Ledgard and Smith, 1992). In almonds, Weinbaum et al. (1987) suggested that a 50\% decrease in the $\%$ NDFF in new growth from year to year implies that $50 \%$ of the $\mathrm{N}$ in new growth comes from plant reserves.

Percent NDFF declined at a similar rate in the enriched plants in this study ( $\approx 40 \%$ decrease per year) implying that plant reserves are a very important long term $\mathrm{N}$ source (data not shown). This level of available stored $\mathrm{N}$ is much higher than the $10 \%$ estimated for red raspberry by Dean et al. (2000), but is consistent with 
work in other perennial crops such as apples and pears (Neilsen et al., 2001; Sanchez et al., 1991).

A pot study using 'Chester Thornless' blackberry concluded that primocanes were a large reserve of fertilizer $\mathrm{N}$; however, this $\mathrm{N}$ was not remobilized to other plant parts the following season (Malik et al., 1991). The same pattern was observed in this study. Primocanes ended the 2001 season with $\approx 75 \%$ of the NDFF content present in the plant (excluding roots). In 2002, floricanes and fruiting laterals (formerly primocanes in 2001) retained the highest mass of NDFF in all treatments and did not remobilize this $\mathrm{N}$ to other plant parts (Fig. 2). In September, floricane tissues still contained an average of $62 \%$ of the mass of NDFF in the plant. This partitioning strategy ensures reproduction is supported with stored $\mathrm{N}$ while vegetative growth is more dependent on exogenous $\mathrm{N}$. The decline in stored fertilizer $\mathrm{N}$ throughout the season was primarily attributed to removal through fruit harvest and leaf senescence.

Although the total amount of labeled $\mathrm{N}$ present in aboveground plant components did not change from December 2001 to April 2002 (Fig. 2), the \%NDFF declined over the same time period (Fig. 3). This indicates a dilution of labeled $\mathrm{N}$ with new uptake from the soil early in the season. For the remaining portion of the season, overall total aboveground plant \%NDFF remained
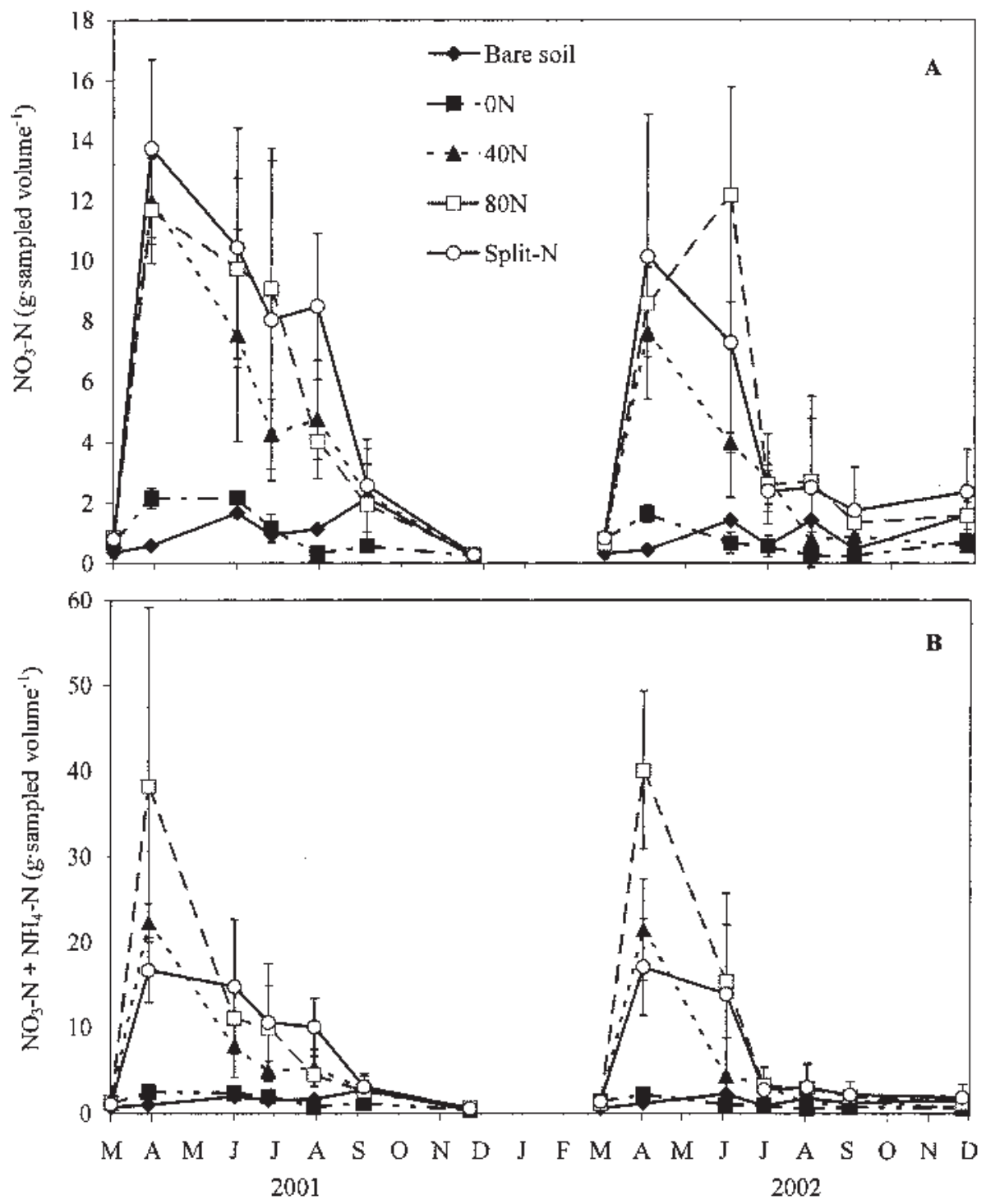

constant or declined slightly during 2002 for all treatments to a low of 3\% to 6\% NDFF (Fig. 3). However, the $80 \mathrm{~N}$ treatment maintained a significantly higher \%NDFF per plant than either the $40 \mathrm{~N}$ or split-N treatments from April to August 2002 (data not shown).

NDFF concentration in the plant parts varied throughout the season, and was generally highest in the $80 \mathrm{~N}$ treatment and lowest in the split-N treatment (data not shown). In April, \%NDFF in the $80 \mathrm{~N}$ floricane tissues (20\%) was significantly higher than in the other treatments (7\% for the $40 \mathrm{~N}$ treatment, and $6 \%$ for the split-N treatment).

In April, roots contained $7 \%$ to $14 \%$ NDFF, a concentration as high or higher than in all other tissues at this time, except for floricane tissues. The roots were probably a sizable sink for fertilizer $\mathrm{N}$, particularly for the $80 \mathrm{~N}$ treatment which received an excess of $\mathrm{N}$.

Fruit N, yield, and Plant growth Variables. Yield differences among treatments were not significant in 2001. However, in 2001 and 2002, the $0 \mathrm{~N}$ treatment tended to have the lowest yield and the split-N treatment had the highest yield. This trend became significant in 2002 (Table 1). A lack of yield response to fertilizer rate has been observed in previous red raspberry research in the Pacific Northwest (Chaplin and Martin, 1980; Kowalenko, 1994). Observed yield increases due to higher fertilizer rates were sometimes directly related to an increase in berry weight (Kowalenko, 1981), although this was not always the case (Chaplin and Martin, 1980). In this study, a significant increase in berry weight in the fertilized treatments compared to the $0 \mathrm{~N}$ treatment was observed both years (Table 1).

A trend was observed in 2001, which became significant in 2002 , for primocanes to be longer in the fertilized treatments than in the $0 \mathrm{~N}$ treatment (Table 1). Canes in the fertilized treatments were an average of 0.2 to $0.4 \mathrm{~m}$ longer in 2001 and 0.6 to $0.8 \mathrm{~m}$ longer in 2002 than in the $0 \mathrm{~N}$ treatment. Most studies examining the $\mathrm{N}$ requirements of raspberry have pruned excess primocanes and topped the remaining primocanes during the winter (Dean et al., 2000; Kowalenko, 1994; Kowalenko et al., 2000). While some growers follow this practice, the removal may have masked trends of a decrease in primocane length due to insufficient $\mathrm{N}$. When the removed prunings were measured, their dry weight was found to increase with increasing $\mathrm{N}$ rate (Kowalenko et al., 2000). Strik and

Fig. 4. (a) Soil $\mathrm{NO}_{3}-\mathrm{N}$ and (b) total inorganic $\mathrm{N}$ content $\left(\mathrm{NO}_{3}-\mathrm{N}+\mathrm{NH}_{4}-\mathrm{N}\right)$ for the sum of two incremental depth (0 to $15 \mathrm{~cm}+15$ to $30 \mathrm{~cm}$ ) measurements for four $\mathrm{N}$ applications, $0 \mathrm{~kg} \cdot \mathrm{ha}^{-1}$ of $\mathrm{N}(0 \mathrm{~N}), 40 \mathrm{~kg} \cdot \mathrm{ha}^{-1}$ of $\mathrm{N}(40 \mathrm{~N}), 80 \mathrm{~kg} \cdot \mathrm{ha}^{-1}$ of $\mathrm{N}(80 \mathrm{~N})$, and $40 \mathrm{~kg} \cdot \mathrm{ha}^{-1}$ of $\mathrm{N}$ in March $+40 \mathrm{~kg} \cdot \mathrm{ha}^{-1}$ of $\mathrm{N}$ in May (split-N), as well as a bare soil plot. Measurements were made at the experimental site from Mar. through Dec. of 2001 and 2002. The sampled volume was $0.14 \mathrm{~m}^{3}$, equivalent to the estimated volume occupied by a raspberry plant. Bars indicate standard deviation of the mean $(n=3)$. 
Cahn (1999) showed, in 2 out of 3 years, that topping primocanes reduced yields per plant. The decrease in primocane length in the $0 \mathrm{~N}$ plants mimicked the practice of topping and marked an overall decline in their vigor.

Average $\mathrm{N}$ concentration in the fruit was higher for all fertilized treatments than for the $0 \mathrm{~N}$ treatment in 2002. The $80 \mathrm{~N}$ treatment had a significantly higher \%NDFF in the fruit than the other fertilized treatments in both years (Table 1). The amount of $\mathrm{N}$ removed in the $80 \mathrm{~N}$ fruit in 2001 was significantly higher than the $\mathrm{N}$ removed in the $40 \mathrm{~N}$ or split- $\mathrm{N}$ fruit. However, in 2002, the most $\mathrm{N}$ was removed in the split- $\mathrm{N}$ fruit (Table 2). In 2002, significantly more fertilizer $\mathrm{N}$ was found in the split-N vs. $40 \mathrm{~N}$ fruit (Table 3), indicating that some of the second half of the split application was allocated to fruit growth the second year.

Soil Nitrogen CONCENTRATion. Seasonal patterns for soil N status (0 to $0.3 \mathrm{~m})$ are presented in Fig. 4 . Similar patterns were apparent in a shallower depth (0 to $0.15 \mathrm{~m}$ ) which was evaluated in both years (data not shown). In the bare soil and $0 \mathrm{~N}$ treatment, $\mathrm{NO}_{3}-\mathrm{N}$ concentrations remained below $3.6 \mathrm{~g} / \mathrm{sampled}$ volume throughout both years, whereas in the fertilized plots, $\mathrm{N}$ application caused a sharp increase in $\mathrm{NO}_{3}-\mathrm{N}$, which then declined throughout the growing season (Fig. 4A). Bare soil $\mathrm{N}$ values in this study [estimated $20 \mathrm{~kg} \cdot \mathrm{ha}^{-1}$ ] were lower than those seen previously at this experimental site [estimated $70 \mathrm{~kg} \cdot \mathrm{ha}^{-1}$ ] (Mohadjer et al., 2001). This is most likely because in the previous study (Mohadjer et al., 2001), all plots received irrigation throughout the growing season while the bare soil in this study did not. Soil $\mathrm{N}$ concentrations for fertilized plots in this study were also lower than those measured in British Columbia due to high rates of atmospheric deposition and high $\mathrm{N}$ levels in their irrigation water (Dean et al., 2000). However, the magnitude and timing of the soil inorganic $\mathrm{N}$ response to fertilization was the same as that observed in kiwifruit (Ledgard et al., 1992).

In 2001, $\mathrm{NO}_{3}-\mathrm{N}$ levels in the top $0.3 \mathrm{~m}$ declined between April and September (Fig. 4A) at which point all fertilized plots fell below $\mathrm{NO}_{3}-\mathrm{N}$ levels considered excessive $(<30$ ppm or 2.4 $\mathrm{g} /$ sampled volume) (Marx et al., 1999). Nitrate patterns were similar in 2002. There were no obvious trends in weather data (data not shown).

Some of the decline in $\mathrm{NO}_{3}-\mathrm{N}$ levels observed throughout the growing season was probably due to irrigation-driven leaching. Also, some of the labile $\mathrm{N}$ may have become immobilized into the organic matter fraction since plant uptake cannot account for the large difference in soil $\mathrm{N}$ values between April and December. Little inorganic $\mathrm{N}$ was present in the soil by December, and thus at risk for additional leaching during the Pacific Northwest's rainiest season. In addition, conditions are unfavorable for the mineralization of organic $\mathrm{N}$ at this point in the season (Sattell et al., 1999). Late in the season in both years, the bare soil plots had a higher inorganic $\mathrm{N}$ content than the soil in the $0 \mathrm{~N}$ plots showing plant removal of $\mathrm{N}$ in the $0 \mathrm{~N}$ plots. In studies where labeled fertilizer $\mathrm{N}$ has been tracked in the soil, $93 \%$ and $99 \%$ of the fertilizer $\mathrm{N}$ recovered in the topsoil was found in the organic fraction (Naraguma et al., 1999; Retamales and Hanson, 1989). Ledgard et al. (1992) concluded that most of the fertilizer $\mathrm{N}$ would remain in stable humus forms. Although this $\mathrm{N}$ may be released over the long term, it was not released during the length of this study.

An average of $\approx 1 \mathrm{~g} /$ sampled volume with a maximum of 2.2 $\mathrm{g} /$ sampled volume of $\mathrm{NO}_{3}-\mathrm{N}$ was available in the $0 \mathrm{~N}$ plots from the soil at any given sample time (Fig 4A). However, the soil and storage $\mathrm{N}$ pools were not adequate to provide for $\mathrm{N}$ needs over time, as shown by the decline in primocane length, berry weight, and yield in the $0 \mathrm{~N}$ plants (Table 1).

Fertilizer uptake by the plants was small in April, while soil fertilizer $\mathrm{N}$ levels were still high. The difference between $\mathrm{NO}_{3}-\mathrm{N}$ levels in the bare soil and fertilized plots in April 2001 was $\approx 12$ $\mathrm{g}$ /sampled volume (Fig. 4A). When comparing the soil concentrations (Fig. 4) to NDFF uptake (Fig. 2), it is clear that when plants reached the peak of their fertilizer N-uptake in July 2001 $(6.5 \mathrm{~g} /$ plant for the $80 \mathrm{~N}$ treatment) high levels of inorganic $\mathrm{N}$ remained in the top $0.15 \mathrm{~m}$ of soil $(\approx 5 \mathrm{~g} / \mathrm{sampled}$ volume for fertilized plots).

Our results indicate that while plants in the $0 \mathrm{~N}$ treatment showed no significant differences in dry weight or total $\mathrm{N}$ content compared to the fertilized treatments, skipping a year of fertilization or consistently applying no $\mathrm{N}$ is not advisable, as raspberry plants in a production system need additional $\mathrm{N}$ to appropriately account for their $\mathrm{N}$ requirements. The lack of differences between fertilized and unfertilized treatments may have been due to reserves accumulated before this study began which buffered the $0 \mathrm{~N}$ treatment against a drop in dry weight and total $\mathrm{N}$ for the length of this study. However, either a single early application or a split application of $40 \mathrm{~kg} \cdot \mathrm{ha}^{-1}$ of $\mathrm{N}$, depending on management practices, is probably sufficient to maintain production while maximizing fertilizer recovery in mature red raspberry in the Pacific Northwest. The increased fertilizer $\mathrm{N}$ uptake by the $80 \mathrm{~N}$ treatment suggests luxury consumption at the expense of soil $\mathrm{N}$ uptake.

\section{Literature Cited}

Chaplin, M.H. and L.W. Martin. 1980. The effect of nitrogen and boron fertilizer applications on leaf levels, yield and fruit size of the red raspberry. Commun. Soil Sci. Plant Anal. 11:547-556.

Dale, A. 1989. Productivity in red raspberries, p. 185-228. In: J. Janick (ed.). Horticultural reviews. vol. 11. AVI Publ., Westport, Conn.

Dean, D.M., B.J. Zebarth, C.G. Kowalenko, J.W. Paul, and K. Chipperfield. 2000. Poultry manure effects on soil nitrogen processes and nitrogen accumulation in red raspberry. Can. J. Plant Sci. 80:849-860.

Feigenbaum, S., H. Bieloria, Y. Erner, and S. Dasberg. 1987. The fate of ${ }^{15} \mathrm{~N}$ labeled nitrogen applied to mature citrus trees. Plant and Soil 97:179-187.

Hart, J., B. Strik, and A. Sheets. 2000. Caneberry fertilizer guide. Ore. State Univ. Ext. Serv. FG 51.

Hauck, R.D. and J.M. Bremner. 1976. Use of tracers for soil and fertilizer nitrogen research. Adv. Agron. 28:219-266.

Khemira, H., T.L. Righetti and A.N. Azarenko. 1998. Nitrogen partitioning in apple as affected by timing and tree growth habit. J. Hort. Sci. Biotechnol. 73:217-223.

Kowalenko, C.G. 1981. Response of raspberries to soil nitrogen and boron applications. Commun. Soil Sci. Plant Anal. 12:1151-1162.

Kowalenko, C.G. 1994. Growing season dry matter and macroelement accumulations in 'Willamette' red raspberry and related soil-extractable macroelement measurements. Can. J. Plant Sci. 74:565-571.

Kowalenko, C.G., J.C.W. Keng, and J.A. Freeman. 2000. Comparison of nitrogen application via a trickle irrigation system with surface banding of granular fertilizer on red raspberry. Can. J. Plant Sci. 80:363-371.

Ledgard, S.F., G.S. Smith, and M.S. Sprosen. 1992. Fate of ${ }^{15} \mathrm{~N}$ labeled nitrogen fertilizer applied to kiwifruit (Actinidia deliciosa) vines. I. ${ }^{15} \mathrm{~N}$ recovery in plant and soil. Plant and Soil 147:49-57.

Ledgard, S.F. and G.S. Smith. 1992. Fate of ${ }^{15} \mathrm{~N}$ labeled nitrogen fertilizer applied to kiwifruit (Actinidia deliciosa) vines. II. Temporal changes in ${ }^{15} \mathrm{~N}$ within vines. Plant and Soil 147:59-68.

Malik, H., D. Archbold, and C.T. MacKown. 1991. Nitrogen partitioning by 'Chester Thornless' blackberry in pot culture. Hortscience 26: 1492-1494.

Marx, E.S., J. Hart, and R.G. Stevens. 1999. Soil test interpretation 
guide. Ore. State Univ. Ext. Serv. EC 1478.

Mohadjer, P., B.C. Strik, B.J. Zebarth, and T.L. Righetti. 2001. Nitrogen uptake, partitioning and remobilization in 'Kotata' blackberry in alternate-year production. J. Hort. Sci. Biotechnol. 76:700-708.

Naraguma, J., J.R. Clark, R.J. Norman, and R.W. McNew. 1999. Nitrogen uptake and allocation by field-grown 'Arapaho' thornless blackberry. J. Plant Nutr. 22:753-768.

Neilsen, D., P. Millard, G.H. Neilsen, and E.J. Hogue. 2001. Nitrogen uptake, efficiency of use, and partitioning for growth in young apple trees. J. Amer. Soc. Hort. Sci. 126:144-150.

Oregon Agriculture Statistics Service. 2003. Oregon 2002 berry report. Salem, Ore. p. 1.

Reickenberg, R.L. and M.P. Pritts. 1996. Dynamics of nutrient uptake from foliar fertilizers in red raspberry. J. Amer. Soc. Hort. Sci. 121: $158-163$

Retamales, J.B. and E.J. Hanson. 1989. Fate of ${ }^{15 N}$-labeled urea applied to mature highbush blueberries. J. Amer. Soc. Hort. Sci. 114:920-923.

Retamales, J.B. and E.J. Hanson. 1992. Effect of nitrogen source and timing on highbush blueberry performance. HortScience 27: $1265-1267$.

Sanchez,E.E., T.L. Righetti,D. Sugar, and P.B.Lombard. 1991. Recycling of nitrogen in field-grown 'Comice' pears. J. Hort. Sci. 66:479-486.

Sanchez, E.E. T.L. Righetti, D. Sugar, and P.B. Lombard. 1992. Effects of timing of nitrogen application on nitrogen partitioning between vegetative, reproductive, and structural components of mature 'Comice' pears. J. Hort. Sci. 1:51-58.

SAS Institute, Inc. 1999. SAS user's guide. version 8. SAS Inst., Cary, N.C.

Sattell, R., R. Dick, D. Hemphill, J. Selker, F. Brandi-Dohrn, H. Minchew, M. Hess, J. Sandeno, and S. Kaufman. 1999. Nitrogen scavenging: using cover crops to reduce nitrate leaching in Western Oregon. Extension Management-OSU EM 8728.

Strik, B.C. and H.K. Cahn. 1999. Pruning and training affect yield but not machine harvest efficiency of 'Meeker' red raspberry. HortScience 34:611-614.

Taylor, B.K. and B. van den Ende. 1969. The N nutrition of the peach tree IV. Storage and mobilization of N in mature trees. Austral. J. Agr. Res. 20:869-881.

Tisdale, S.L., J.L. Havlin, J.D. Beaton, and W.L. Nelson. 1999. Soil fertility and fertilizers. $6^{\text {th }}$ ed. Prentice-Hall, Inc., N.J.

Varvel, G.E. and T.A. Peterson. 1990. Nitrogen fertilizer recovery by corn in monoculture and rotation systems. Agron. J. 82:935-938.

Weinbaum, S.A., I. Klein, and T.T. Muraoka. 1987. Use of nitrogen isotopes and a light-textured soil to assess annual contributions of nitrogen from soil and storage pools in mature almond trees. J. Amer. Soc. Hort. Sci. 112:526-529.

Wright, C.J. and P.D. Waister. 1980. Seasonal changes in the mineral nutrient content of the raspberry. Acta Hort. 112:295-304. 